\title{
The Ethics of Warfare in the Jewish Tradition
}

\author{
Michael Walzer
}

Received: 16 August 2012 / Accepted: 20 August 2012 /

Published online: 19 September 2012

(C) Springer Science+Business Media B.V. 2012

I am not going to tell you this evening how Jews (or anyone else) should think about the war in Iraq, or about the treatment of prisoners at Guantanamo, or about different incidents in the "war" on terrorism, or about the 2006 Lebanon war or the 2009 war in Gaza. This is not a political talk. I want to look back on the treatment of war, and more particularly, the ethics of war, in the Jewish tradition. How does war figure in the Bible, the Talmud, in Jewish law (halakha), in scholarly commentaries and rabbinic responsa?

And with regard to this material, I am going to adopt a typically Jewish approach (that is, a critical approach): I will begin by discussing the deficiencies and omissions of the Jewish account of the ethics of warfare. I will say something later on about the strengths of this account. But the deficiencies are important, especially so from a Zionist perspective (which is my own perspective), because they have an important cause: namely, the centuries of statelessness. Now that there is a Jewish state, legal scholars and philosophers need to look carefully and critically at exilic understandings of politics. In most of the world, after all, political theory in general, and ideas about war in particular, are a reflection of decisions made and policies adopted by sovereign states. And for almost 2000 years, the Jews were without sovereignty. There were, of course, autonomous or semi-autonomous Jewish communities in the diaspora, and these communities provided a political space for power-seeking (even if there wasn't much power to seek), and for decision-making, and for debates about what decisions to make and who should make them - so there is a long tradition of Jewish political and legal argument. But the Jews had no "high" politics, no politics of war and peace, from the time of Bar Kokhba (135 C.E.) to the time of Ben-Gurion (1948). The incompleteness of Jewish thought about war derives from this central historical fact.

I will need a point of comparison for my analysis of what the rabbis produced, and I am going to use Catholic just war theory for that purpose-since for most of our

M. Walzer ( $\square)$

School of Social Science, Institute for Advanced Study, Einstein Drive, Princeton, NJ 08540, USA

e-mail: walzer@ias.edu 
2000 years of statelessness, the Catholics had states, many states, and the arguments that went on about warfare in those states are the major source of contemporary Western (secular as well as religious) arguments about war and morality. They have a basic two-part structure-jus ad bellum, the justice of the war itself, deals with the decision to begin fighting, and jus in bello, the justice of the conduct of war, deals with behavior on the battlefield. Along with a lot of other people, I have argued that we need to add a third part: jus post bellum, justice after the war, but I won't be talking about that this evening. I am going to focus on standard just war theory, and especially on four features of it that seem to me critically important: the first relates to the overall theoretical framework and what we might think of as the "reach" of the theory; the second and third have to do with the description of just and unjust warsthe Jewish classification scheme is very different; and the fourth has to do with warfare itself, how the actual battles are fought, particularly with regard to the treatment of civilians who find themselves, unwillingly and unhappily, on or near the battlefield. I will try to explain each of these features as they appear in the theory of just war, very briefly, and then contrast the relevant Jewish arguments, focusing as best I can on mainstream rabbinic texts-I will quote Maimonides' Mishneh Torah, the most important medieval code, whenever possible.

The first feature of just war theory is its inclusiveness: it is derived from natural law, which is to say, from human reason, not from revelation and not from any particular history. So it is easily secularized and it has universal reach: that is, it claims to set moral or legal limits on all human warfare. The rules of jus ad bellum and jus in bello are intended to regulate all wars or, at least, to shape our judgments of all wars, whoever fights them, whenever and wherever they are fought. The Jewish account of war, by contrast, is derived from Biblical texts, chiefly the book of Deuteronomy; it is an aspect of revealed law, Torah from Sinai, and it seems to apply only to Jewish warfare. The two categories of war described by the rabbis, "[divinely] commanded wars" and "permitted (or optional) wars," are commanded and permitted to the Jews alone. Gentile warfare, though Jews were often its victims, is mostly a blank space in post-Biblical Jewish literature. Or rather, the space is filled by dirges, laments, and chronicles of death and destruction, but not by legal or moral analysis. It seems that gentile war-making is imagined, quite reasonably, I suppose, from the standpoint of the Jews, as an entirely lawless activity - but not lawless in the sense that it violates the law; rather, in the sense that it exists outside the law: it is, as the elder Rabbi Kook says somewhere, like the fighting of desert wolves. The commandment not to murder applies to gentiles and Jews alike, obviously, but there is no command or permission to fight addressed to the gentiles and no explicit ban on fighting either. The Noahide code, which is often taken to be the Jewish version of natural law, says nothing about war-unless the commandment to set up courts is taken to apply to international society. Many rabbis today would say that the Talmudic rule dina d'malkhuta dina (the law of the kingdom is law) - the foundation of exilic halakha - should be extended to require a recognition of international law, which would then be obligatory for both Jews and non-Jews. But I have not seen any texts that acknowledge the moral significance of international law.

Biblical writers, by contrast, have a lot to say about gentile war-making: in the prophetic books, for example, the Assyrians are frequently condemned for their cruelty in war. But the kings of Assyria and Babylonia are at the same time identified 
as the instruments of God's wrath, even as God's servants, employed to punish the religious corruption of Israel. I don't know of similar post-Biblical treatments of Roman or Spanish or Turkish or German warfare (well, there are descriptions of the Holocaust as an act of divine punishment, but most Jews find them, as I do, both incredible and terribly cruel). The rabbis generally don't seem to have imagined themselves as the world-historical judges or moral critics of gentile wars. Unlike the Biblical prophets, they display little interest in international politics - but then, the prophets were speaking from within a state, however rudimentary its political structure may have been, and the rabbis lived in exile, in a condition of statelessness.

The second feature of just war theory is the secularization of justice as it relates to war. The theory took shape, in part, as a response to the actual experience of crusading warfare in the 11 th and 12th centuries. Thomas Aquinas seems to have defended the justice of the crusades, but over time just wars came to be understood as the opposite of holy wars. Or, to put it more sharply, according to late medieval and early modern Catholic writers, wars fought for religious purposes, to convert people to the true faith or to punish idolaters, cannot be justified; these are unjust wars. The only justification for war, writes the Spanish Dominican Francisco de Vitoria, is "an injury received."

In the Jewish tradition, this distinction between religious and secular purposes was never firmly drawn (though I don't doubt that many contemporary Jewish writers would happily accept it). The rabbinic concept of the "commanded war"-commanded, remember, by God - is designed to accommodate the wars fought by Joshua to conquer the promised land and to punish or, more accurately, exterminate the idolaters who lived there. The concept also extends to wars in defense of the land against later invaders, like Saul's disastrous war against the Philistines. So it includes what in Western theory would be called holy wars as well as what would be called just (defensive) wars. Maimonides says, to be sure, that "no coercion to accept the Torah and the Commandments [should be] practiced on those who are unwilling to do so"- which would rule out at least some forms of crusading warfare. But he also says that the sole aim of a Jewish king "should be to uplift the true religion, to fill the world with righteousness, to break the arm of the wicked, and to fight the battles of the Lord." The king's soldiers should know, he insists, that they are "fighting for the oneness of God." This is a description of war that comes painfully close to the Christian crusade and the Islamic jihad. The idea that war is a this-worldly activity that can have only limited and secular purposes (like self-defense) is entirely absent here - or it is explicitly repudiated. I would suggest that a secular understanding of warfare, and of foreign policy generally, depends on the actual experience of international politics, which is to say, on the competitive struggles and mutual adjustments and accommodations through which states achieve some kind of co-existence. Today, most Jewish writers who work within the religious tradition would defend a doctrine of limited war and would probably argue that only defensive wars are now "commanded" and that the "battles of the Lord" await the coming of the messiah. But I have not seen it argued, as writers outside the tradition would say, that such "battles" should not be fought even then.

The third feature of just war theory is its sharp negativity. The theory of just war is also, and most importantly, a theory of unjust war: wars to convert or punish the heathen, wars of imperial conquest or dynastic aggrandizement, wars for plunder and 
slaves - all these are ruled out. In Jewish thought, by contrast again, the two categories of commanded and permitted wars were not (until recent times) extended to what we might think of as their natural third: that is, prohibited wars. There are intimations of prohibition in the Talmud and the commentaries, particularly with regard to wars of conquest (the rabbis seem to have disliked, for example, the expansionist wars of the Hasmoneans [167-160 B.C.]). In the 20th century, under the impetus of Zionism and statehood, efforts were made to develop those intimations, on the theory that prohibition is the necessary background to command and permission. As Avi Ravitsky has argued, any war that isn't commanded or permitted is "by definition" prohibited. But this idea of prohibition has not yet been systematically applied in criticism of particular wars, the way the theory of just and unjust wars is commonly applied. And some of the early accounts of permitted wars make it radically unclear that there is anything left to prohibit. Maimonides, for example, permits a Jewish king (he is thinking of King David) to fight in order "to extend the borders of Israel and to enhance his greatness and prestige." "His" here refers to the king; a war for God's greatness and prestige would presumably be a commanded, not a permitted, war. In any case, neither of these are prohibited wars as, in my view, they should be.

The rabbis of the Talmudic period apparently did not believe that it was possible to stop political rulers from fighting for the sake of their own power and prestige. They were realists, these rabbis, and extraordinarily honest (as the Biblical writers had also been) in their descriptions of royal behavior. There is a dramatic moment, described in tractate Sanhedrin of the Babylonian Talmud (19a-b), when the members of the Sanhedrin, Israel's judges, fail to bring King Yannai (one of the Hasmonean rulers) to judgment because he threatens them and they fear his power. That moment resonates, I think, in rabbinic discussions of permitted wars. Remember how the elders of Israel came to Samuel to ask for a king to fight on their behalf against invading Midianites and Philistines. The resigned wisdom of the Talmud holds that once you have a king like that, he isn't only going to defend you; he is also going to aggrandize himself. The rabbis seem to have thought that his wars are the price you pay for your security (it is true, of course, that his wars may make you insecure...). In any case, there is little readiness among the rabbis to criticize the king's wars. It seems plausible to say that if they had lived in a state with a succession of kings and many wars, they would have learned to be critics. Maybe they will learn to be critical in a secular democratic state - though it is possible that what they (or some of them) will be critical about is the state's refusal to fight with sufficient zeal and for every inch of the promised land.

The fourth feature of just war theory is its commitment to the casuistic investigation of military conduct: this is the crucial requirement of any serious and sustained argument about jus in bello. Moral casuistry is the application of conscience to its cases (just as legal casuistry is revealed in the development of case law: halakha develops in just this way). The Catholics, of course, had a lot of cases since they had a lot of armies in the field, and the Jews had hardly any at all since we had no armies in the field. On the other hand, why shouldn't the victims of warfare construct their own case law, their own account of injuries and suffering that should never have been inflicted? There is one wonderful example of this sort of thing, where Maimonides, working from a midrashic text and speaking for generations of refugees, proposes a novel law of siege warfare: a city, he says, can only be surrounded on three sides - so 
that the civilian inhabitants can flee. There are both bad strategic arguments and very good moral arguments for this rule; Nachmonides, in particular, stresses the crucial moral argument: care for civilians. In any case, what this means is that a city cannot be surrounded, cannot be besieged at all-for the object of a siege is to lock the city's inhabitants into the city, so that they exhaust the food supply and then press the garrison to surrender. There are other Jewish texts that suggest the permissibility of this kind of warfare, without citing the Maimonidian rule. In truth, Maimonides' lovely line was never developed into a full-scale doctrine, written from the standpoint of the victims of war, and meant to govern what armies can and cannot do. But his defense of the civilian population would fit very well into a new Jewish theory of warfare - for the safety of civilians is the primary goal of jus in bello.

And so would the highly developed Catholic theory of "double effect" fit into a new Jewish theory. This is an effort to account for and set limits on what we now call "collateral damage" in warfare - civilian deaths are the key example. The argument is that when this damage is the unintended side-effect of a legitimate military operation, an operation aimed, that is, at a military target, and when the damage isn't disproportionate to the probable benefits of attacking the target, it is permitted. The IDF made exactly this argument in the Lebanon war of 2006 and again in Gaza during 2009 with regard to the bombing of sites from which rockets had been launched against Israel: these sites were legitimate military targets so long as there weren't large numbers of civilians close by. When small numbers of civilians are killed in such attacks - well, the deaths are not just, but they are justifiable in the circumstances of war. At the same time, intentional attacks on civilian targets or disproportionate injury to civilian populations are condemned and prohibited.

The overall argument is meant to balance the necessities of war and the value of human life. It is a necessary argument, and yet there is nothing like it in the classical Jewish texts. A number of writers suggest the immorality of killing civilians, and there are significant efforts by the rabbis to find some way to escape, since they cannot repeal, the Biblical commandments to slaughter the idol worshippers of Canaan. (They ruled that it was no longer possible to identify the seven Canaanite nations, the world's populations were too mixed up, so the commandments, thank heaven, had lapsed.) But there is no attempt to address the hard questions about collateral damage. Basically, as the orthodox scholar J. David Bleich has written (I wouldn't trust myself to make such a strong assertion), "there exists no discussion in classical rabbinic sources that takes cognizance of the likelihood of causing civilian casualties in the course of hostilities legitimately undertaken as posing a halakhic or moral problem." That is a difficult sentence; what Bleich is saying is that collateral damage, unintended civilian death, whatever its extent, is not recognized as morally problematic by the rabbis. This is very strange, since Jews were so often among the civilian casualties. But it suggests again that it is the moral questions that soldiers face, far more than the actual injuries they inflict, that drive the development of just war theory - and if you don't have soldiers facing those questions, worrying about them, then you don't get a developed theory.

It would be easy, though, to apply the prohibitions of Catholic doctrine to Jewish war-making: all that is necessary is to expand on the Talmudic principle, from tractate Sanhedrin again, that "nothing is permitted to Jews that is prohibited to gentiles." In context, this has a restricted reference: it would amend halakhic rules only when they 
are more permissive than the Noahide code. It would be a scandal and a discredit to God, the rabbis apparently believed, if Jewish law on any subject was more permissive than the (Jewish) rules pertaining to non-Jews. But the general principle could well be extended to laws made by as well as for the gentiles. If "they" rule out the deliberate targeting or disproportionate killing of civilians, surely "we" must do so too. This argument, however, has not yet been made with regard to warfare.

Now, I believe that these deficiencies in the Jewish account of war (I take them to be deficiencies; we can argue about that...) are the effects of statelessness; they derive from the fact that there were no Jewish political and military leaders present in international society, acting as responsible agents, making decisions about war and peace. Of course, there were Jewish soldiers, even Jewish generals, but not in Jewish armies fighting in defense or aggrandizement of a Jewish state. The most famous Jewish general (before the modern age) is probably Shmuel Ha-Nagid, who led the army of Granada in 11th century Spain, sometimes as a field commander, sometimes as the medieval equivalent of a secretary of defense. Shmuel was also a major poet; he wrote a number of lovely poems celebrating his battles, and in them he seems to assume the justice of his cause; he thanks God for his victories. But he does not address the moral and legal questions that were agitating some of his non-Jewish contemporaries - perhaps because he was leading a gentile army against other gentile armies. In any case, his career was not a common one. Jewish legal writing about warfare in the exilic years was never a reflection on actual responsibilities and consequential decisions.

Had there been a Jewish state, or even better, had there been three or four Jewish states (as there were Catholic and Muslim states), interacting with non-Jewish states in a society of states, I am sure that these deficiencies would have been made up. They will be made up, over time, in the contemporary state of Israel—but only over time; traditionalist religions are very slow to change, and orthodox Judaism is primarily a religion of exile, not of statehood. Its adaptation to statehood is difficult and still incomplete. Many Israelis won't wait; they are already arguing, have been arguing for a long time, in the language provided by just war theory. The Haganah's famous doctrine of the "purity of arms," though the phrase sounds religious, owes much less to halakhic discourse than it does to the just war concept of non-combatant immunity-for arms are "pure" only when they are not used against civilians. And just war theory is surely a desirable source of this prohibition, since it is now widely accepted in the society of states, and Israel is a member of that society.

Since statehood or, better, its absence is the key to my argument, let me give a couple of examples of the difference that statehood makes. The first comes from Biblical times and suggests how the earliest Jewish experience of being, so to speak, "enstated" in the world, the experience of the first commonwealth, produced an account of warfare better than the one the rabbis produced in exile. ${ }^{1}$ The first two chapters of the prophetic book of Amos consist of a series of indictments and condemnations of the countries around Israel and Judah (and then of Israel and Judah themselves), and all the indictments and condemnations of the neighboring countries

\footnotetext{
${ }^{1}$ You can see that I am engaged here in a Zionist enterprise: the negation of the Galut, back to the bible! I am not in fact entirely at ease with this enterprise, but in the case of war I find it sympathetic - though it is still necessary to pick and choose among Biblical texts.
} 
relate to what we would call war crimes. The text seems to presuppose some kind of international law, which applies in exactly the same way to all the states in this small society of states and city-states (the list includes Damascus, Gaza, Tyre, Edom, Ammon, and Moab). This "law of nations" (as Max Weber calls it in his Ancient Judaism) isn't revealed law; it is or appears to be a combination of customary and treaty law. In other words, it is the product of an ongoing interaction among these states, which fight, negotiate, make peace, and fight again. They have very different religions, idolatrous and monotheistic religions according to the Biblical account, but despite their differences they have to deal with one another. And so they work out a rough set of rules for those dealings - an interesting set of rules from a contemporary perspective, because they still apply and still require enforcement (and still are not regularly or effectively enforced). These are the rules: don't violate treaties, don't seek territorial expansion, don't kill civilians, don't engage in ethnic cleansing. I had better illustrate the last of these lest you think me guilty of anachronistic argumentthough obviously ethnic cleansing isn't a modern invention. The rulers of Gaza are condemned (I quote the most recent JPS translation) "because they exiled an entire population." And the same phrase is used in the indictment of Tyre: "because they handed over an entire population to Edom, ignoring the covenant of brotherhood." (This is what is called "transfer" in contemporary Israel, and within recent memory there were advocates of transfer inside the Israeli government; the prophet calls the "exile of a people" by its right name: it is a "transgression.") Conceivably, one could derive a similar set of prohibitions from rabbinic texts, but only with considerable ingenuity. The prohibitions don't leap out of the texts; they were never stated as a set of rules that were actually intended to govern political and military behavior; and of course they were never casuistically applied and developed because there were no armies (until 1948) that required the application.

The second example comes from America, from the experience of statehood that emancipated Jews have in a modern democracy. But I have to start, again, with a Biblical text. Many of you will remember the list of exemptions from battle in Deuteronomy 20, which begins with the following statement: "Is there anyone here who has built a new house but has not yet dedicated it? Let him go back to his home, lest he die in battle and another dedicate it." The next two items on the list exempt anyone who has planted a vineyard but not yet harvested it and anyone who has paid a bride-price but not yet married the woman. The final exemption goes like this: "Is there anyone afraid and disheartened? Let him go back to his home, lest the courage of his comrades flag like his." That seems clear enough: you send home soldiers who are frightened because they may spread fear among their comrades. But that explanation requires only the first word of the phrase "afraid and disheartened," and it was a principle of legal interpretation among the Jews that every word in the Torah had its own specific purpose. Now "disheartened" is the NJPS translation for rach ha-levav, which literally means weak-hearted - and so it is probably just a synonym for fearful or cowardly, a doubled adjective, common in Biblical Hebrew. But it could also mean soft-hearted, and then it would have a purpose of its own. Rabbi Akiba took up this possibility, suggesting that we should learn from this word that compassionate soldiers were also sent home. But this suggestion plays no role in Jewish arguments for almost 2000 years - again, there were no Jewish states making decisions about whom to send into battle and whom to excuse from the fighting. Had there been such 
states, it certainly seems possible, even, I would say, likely, that this Biblical word, interpreted as Rabbi Akiba interpreted it, would have given rise to a Jewish theory of conscientious objection. And then it did exactly that: in 1967, the Bet Din of Boston, listening to a petition from an orthodox Jewish opponent of the Vietnam war, told him that his refusal to fight was justified under Jewish law if he felt compassion for the people he might have to kill. He still had to deal with the US government, and I don't know how his draft board responded to this rabbinic ruling. But what made the ruling possible was the fact that the rabbis were also citizens of a state in which conscientious objection was a practical possibility, something that the citizens had to argue about.

So perhaps my own argument isn't entirely or exclusively a Zionist one, since it isn't only Jewish statehood but also Jewish citizenship in any democratic state, that opens the possibility for the development, elaboration, and revision of the Biblical and Talmudic understanding of warfare. Still, it is the existence of Israel, and the wars that Israel has fought, and the political power of religious Jews in the state, that make this revisionist program urgent. I don't favor, I don't even want to imagine, rabbis making authoritative rulings about political and military issues; that is obviously out of place in a democratic state. I do imagine them joining the democratic debate, just as Catholic bishops do in the U.S., when they apply just war theory, for example, to nuclear deterrence or the invasion of Iraq.

But if there is to be a halakhic doctrine dealing with when to fight and how to fight, a doctrine that commands respect, the four deficiencies that I have identified here will have to be acknowledged and dealt with. I don't doubt that they can be dealt with; the resources of the tradition are strong and deep. And in the process of dealing with the deficiencies, Jewish writers might produce not only a revised Jewish perspective on war and ethics, but also some revisionist proposals for secular theorists. I assume that a majority of Jewish writers will continue to work within the secular theory; it provides, to put it simply, a better account of the morality of war than the rabbis provided. Still, some mutual benefits might come from intellectual interaction. For example, the idea of a permitted or optional war is probably a necessary part of any full classification scheme. Indeed, it has come into the American discussion: when the 2003 invasion of Iraq is called a "war of choice," the unacknowledged source is the Talmudic phrase milhemet reshut (which Menachem Begin used to describe the 1982 Lebanon War). And the idea that follows from this description of a war, an idea that is also present in Israeli arguments, is that we should be suspicious of wars that are not necessary, that have to be "chosen."

At the same time, the principle of optionality loosens the framework of just and unjust in what might be a useful way: just wars presumably should be fought, unjust wars should never be fought. But perhaps there are wars that admit of legitimate choice - wars, for example, that one could rightfully fight but that it might be prudent not to fight, wars that are not so just that they must be fought. The idea of neutrality implies something like this, for on a strict view of justice, neutrality would not be morally possible. If it is possible, then there are, as the rabbis thought, optional wars.

Of course, the interaction between religious and secular writers has to work the other way too. Great Jewish philosophers like Saadia Gaon and Maimonides have demonstrated that it is possible and even necessary to learn from gentile philosophers. And if from philosophers, why not from lawyers and even political theorists? There 
is, indeed, a lot of learning to be done, and there are certainly cases enough for casuistic analysis: the post-Biblical Jewish encounter with war, which the rabbis mostly ignored, is more than sufficient to provide material for reflection: the Hasmonean wars, the Roman wars, the Crusades, the Christian conquest of Spain, the imperial wars of Hapsburgs and Romanovs, the many Balkan wars, the two world wars, and the Arab-Israeli wars. There is no lack of experience, even though, from the year 135 C.E. until 1948, the Jews were overwhelmingly victims rather than agents.

Finally, as I have briefly suggested, there ought to be a doctrine of warfare, a set of laws of war, written, so to speak, on behalf of the victims. A revised and elaborated Jewish doctrine doesn't have to be that; I hope that we are never victims again. But, given Jewish history, a Jewish account of the ethics of war (and peace), whether it is written from a religious or a secular perspective, should incorporate the experience of victimization. Jewish legal scholars and philosophers need to undertake a sustained reflection, which the rabbis never attempted, on what it means to be a noncombatant, a bystander, an innocent person caught up in the terrible coerciveness of war. And we all need to "take cognizance of the likelihood of causing civilian casualties" in the judgments we make of the wars and battles not only of Israel but also of "the nations" generally. Since we are citizens now of states in the society of states, any new Jewish theory of war will certainly apply to everyone; it will be a universal theory. 